\title{
Antimicrobial activity of Brazilian copaiba oils obtained from different species of the Copaifera genus
}

\author{
Adriana Oliveira dos Santos, Tânia Ueda-Nakamura1, Benedito Prado Dias Filho', \\ Valdir F Veiga Junior ${ }^{2}$, Angelo C Pinto ${ }^{3}$, Celso Vataru Nakamura ${ }^{1 /+}$
}

\begin{abstract}
Programa de Pós-Graduação em Microbiologia, Universidade Estadual de Londrina, Londrina, PR, Brasil 'Laboratório de Microbiologia Aplicada aos Produtos Naturais e Sintéticos, Universidade Estadual de Maringá, Av. Colombo 5790, 87020-900 Maringá, PR, Brasil

${ }^{2}$ Departamento de Química, Universidade Federal do Amazonas, Manaus, AM, Brasil ${ }^{3}$ Instituto de Química, Universidade Federal do Rio de Janeiro, Rio de Janeiro, RJ, Brasil
\end{abstract}

The antimicrobial activity of copaiba oils was tested against Gram-positive and Gram-negative bacteria, yeast, and dermatophytes. Oils obtained from Copaifera martii, Copaifera officinalis, and Copaifera reticulata (collected in the state of Acre) were active against Gram-positive species (Staphylococcus aureus, methicillin-resistant S. aureus, Staphylococcus epidermidis, Bacillus subtilis, and Enterococcus faecalis) with minimum inhibitory concentrations ranging from 31.3-62.5 $\mu \mathrm{g} / \mathrm{ml}$. The oils showed bactericidal activity, decreasing the viability of these Gram-positive bacteria within $3 \mathrm{~h}$. Moderate activity was observed against dermatophyte fungi (Trichophyton rubrum and Microsporum canis). The oils showed no activity against Gram-negative bacteria and yeast. Scannning electron microscopy of $\mathrm{S}$. aureus treated with resin oil from $\mathrm{C}$. martii revealed lysis of the bacteria, causing cellular agglomerates. Transmission electron microscopy revealed disruption and damage to the cell wall, resulting in the release of cytoplasmic compounds, alterations in morphology, and a decrease in cell volume, indicating that copaiba oil may affect the cell wall.

Key words: copaiba oil - yeast - dermatophyte - bacteria - Copaifera - leguminoseae

The bacteria responsible for severe post-surgery infections are predominantly Gram-positive (Okdakowska-Jedynak et al. 2003). Staphylococcus aureus is the major cause of community- and hospital-acquired infections. It is responsible for skin or soft-tissue infections, urinary tract infections, gastrointestinal abscesses, peritonitis, lower respiratory tract infections, osteomyelitis, tropical myositis, endocarditis, and bacteriemia (Fung et al. 2001). S. aureus has a formidable ability to rapidly acquire resistance to any antibiotic. The multi-resistance of Gram-positive bacteria to antimicrobial agents is increasing at a alarming rate for many commonly prescribed classes of antimicrobial agents, including the penicillinase-resistant penicillins, other $\beta$-lactams, fluoroquinolones, and macrolides (Zetola et al. 2005). The increasing resistance of bacteria to conventional antibiotics has encouraged intensive efforts to develop new antimicrobial agents that are effective against resistant bacteria. Plants provide great chemical diversity and bioactivity, the exploration of which has led to the development of hundreds of pharmaceutical drugs (Shu 1998).

Copaiba oils are produced by exudation from the trunks of trees belonging to the genus Copaifera. The

Financial support: CNPq, Capes, Programa de Pós-Graduação em Microbiologia, Universidade Estadual de Londrina

+ Corresponding author: cvnakamura@uem.br

Received 4 January 2008

Accepted 28 April 2008 exuded material is a transparent, yellow to light-brown liquid (Veiga-Junior \& Pinto 2002). The medicinal properties of copaiba oils were known among American Indians, who probably observed that animals rubbed themselves on copaiba tree trunks to heal their wounds (Veiga-Junior et al. 2001). The effects attributed to copaiba oils in folk medicine include anti-inflammatory, anti-tetanus, anti-tumour, anti-blenorrhagea, and urinary antiseptic activities. In addition, it has been used to treat bronchitis, skin diseases, ulcers, and syphilis, as well as for healing wounds (Gomes et al. 2007). Pharmacological studies have demonstrated its properties as an anti-inflammatory; gastroprotective; analgesic; wound-cicatrisatial (Paiva et al. 2004a, b, AraújoJunior et al. 2005, Brito et al. 2005, Carvalho et al. 2005, Veiga-Junior et al. 2006, 2007); anti-nociceptive (Gomes et al. 2007); anti-tumour (Lima et al. 2003); insect repellent (Gilbert et al. 1999); and antimicrobial (Costa-Lotufo et al. 2002, Tincusi et al. 2002). The cosmetic industry uses copaiba oils in shampoos, capillary lotions, and bathing foams. Previous studies have demonstrated that the oleoresin did not show cytotoxicity in mammalian cells, induce behavioural alterations, or cause lesions or bleeding in the stomach of treated mice (Gomes et al. 2007, Veiga-Junior et al. 2007).

Many of these studies were performed with commercial oils without botanical identification. Oils from more than 20 species of Copaifera are used in folk medicine in Brazil, and significant differences in chemical composition occur among them (Veiga-Junior et al. 2007). Here, we report the antimicrobial activity of oils from eight species of this genus: Copaifera multijuga, Copaifera martii, Copaifera cearensis, Copaifera paupera, 
Copaifera langsdorffii, Copaifera officinalis, Copaifera lucens, and Copaifera reticulata, collected in the states of Acre and Pará, Brazil.

\section{MATERIALS AND METHODS}

Plant material - The copaiba oils used here were exuded directly from the trunks of the trees. C. multijuga Hayne was collected at Manaus, Amazonas (INPA 82.418); C. officinalis Jacq. was collected at Boa Vista, Rondonia (INPA 191.211); C. reticulata Ducke was collected at Belém, Pará (INPA 61.212); specimens of all three were deposited in the Herbarium of INPA (Manaus). C. reticulata Ducke was collected at Tarauacá, Acre (RB 359.606); C. lucens was collected in Rio de Janeiro, state of Rio de Janeiro (RB 348.717); C. langsdorffii Desf. was collected at Campinas, São Paulo (RB 344.931); C. paupera Dwyer was collected at Tarauacá, Acre (RB 359.599); specimens of these four species were deposited in the Herbarium of the Jardim Botânico in Rio de Janeiro. C. martii was collected at Tapará, Pará (DC 349) and the sample was deposited in the Herbarium Chico Mendes (Rio de Janeiro). C. cearensis Huber was collected in Minas Gerais (SP 55.425) and the sample was deposited in the Herbarium of the Instituto de Botânica da Universidade de São Paulo.

Microorganisms - The test organisms included Grampositive bacteria: S. aureus ATCC 25923, Bacillus subtilis ATCC 6623, Staphylococcus epidermidis ATCC 12228, methicillin-resistant S. aureus (MRSA) ATCC 33591, and Enterococcus faecalis ATCC 29212; and Gram-negative bacteria: Escherichia coli ATCC 25922, Pseudomonas aeruginosa ATCC 27853, Proteus mirabilis ATCC 25933, Klebsiella pneumoniae ATCC 13883, Shigella flexinerii ATCC 12022, and Enterobacter cloacae ATCC 13047. Bacteria were grown in Mueller-Hinton broth (Difco Becton Dickinson Co., Sparks, Maryland, USA) at $37^{\circ} \mathrm{C}$ for $24 \mathrm{~h}$ and maintained on slopes of nutrient agar (Difco). The yeasts Candida albicans ATCC 10231, Candida tropicalis ATCC 28707, and Candida parapsilosis ATCC 22019 were stored in water suspensions at room temperature and subcultured in Sabouraud-dextrose broth before being used in each test. The filamentous fungi Trichophyton rubrum ATCC 28189, Trichophyton mentagrophytes ATCC 4481, Microsporum canis ATCC 32903, and Microsporum gypseum ATCC 14683 were subcultured every 15 days to prevent pleomorphic transformations. The yeast and dermatophyte fungi were grown on Sabouraud-dextrose agar (Merck SA, São Paulo, Brazil) at $37^{\circ} \mathrm{C}$ or $28^{\circ} \mathrm{C}$, respectively. All standard microorganisms were kindly provided by the Instituto Oswaldo Cruz, Rio de Janeiro, Brazil.

Antibacterial assay - The minimum inhibitory concentrations (MIC) of copaiba oils and reference antibiotics (tetracycline, vancomycin, penicillin, and oxacillin from Sigma Chemical Co., St. Louis, Missouri, USA) were determined by microdilution techniques in Mueller-Hinton broth (Difco) for Gram-positive and Gramnegative bacteria (CLSI 2005a). The assay was carried out in 96-well microtitre plates. Each oil was mixed with an inoculum prepared in the same medium at a density adjusted per tube to 0.5 of the McFarland scale $\left(10^{8}\right.$ bacterial cells) and diluted 1:10 for the broth microdilution procedure. Microtitre trays were incubated at $37^{\circ} \mathrm{C}$ and the MICs were recorded after $24 \mathrm{~h}$ of incubation. The MIC was defined as the lowest concentration of compounds that produced $80 \%$ reduction in visible growth compared with the control. The minimum bactericidal concentration was defined as the lowest concentration yielding negative subcultures or only one colony, when subcultured in Mueller-Hinton agar (MHA) without test compound. These tests were performed in duplicate on separate occasions.

Antifungal assay - The antifungal assay was performed by microdilution techniques in sterile flatbottom microplates (CLSI 2005b, c). The MICs of copaiba oils and reference drugs (nystatin, fluconazole, and amphotericin B) were determined by microdilution techniques in RPMI 1640 (Sigma Chemical Co., Missouri, USA) and approximately $10^{4}$ spores or $10^{5}$ yeast were inoculated in a total volume of $100 \mu \mathrm{l}$. The plates were incubated at $28^{\circ} \mathrm{C}$ for $48 \mathrm{~h}$ for yeast and $72 \mathrm{~h}$ for dermatophytes. MIC was defined as the lowest concentration of oil at which the microorganism tested did not show visible growth. Each experiment was performed twice on different occasions.

Time-kill curve methodology - The antibacterial activity of $C$. martii against $S$. aureus and MRSA was studied over a range of multiples of the MIC $(62.5 \mu \mathrm{g} / \mathrm{ml})$, from 0.12 to $2.0 \mathrm{X}$ MIC. Tests were performed in triplicate and incubated at $37^{\circ} \mathrm{C}$. At predetermined time points $(0,3,6,9,12,24,48 \mathrm{~h})$, a $100 \mu \mathrm{l}$ sample was removed from each test suspension, serially diluted in sterile saline, and plated on MHA plates for colony count determination. Data from triplicate runs were averaged and plotted as $\log$ CFU/ml versus time (h) for each time point (CLSI 2005a).

Scanning electron microscopy - S. aureus treated with $C$. martii ( 31.5 and $50 \mu \mathrm{g} / \mathrm{ml}$ ) was collected by centrifugation after $3 \mathrm{~h}$ incubation at $37^{\circ} \mathrm{C}$, washed in PBS, and fixed with $2.5 \%$ glutaraldehyde in $0.1 \mathrm{M}$ sodium cacodylate buffer containing $1.0 \mathrm{mM} \mathrm{CaCl}_{2}$. After fixation, small drops of the sample were placed on a specimen support with poly-L-lysine. Subsequently, the samples were dehydrated in graded ethanol, critical-point dried in $\mathrm{CO}_{2}$, coated with gold and observed on a Shimadzu SS-550 scanning electron microscope.

Transmission electron microscopy - The bacterium S. aureus, collected from exponential phase, was cultured with $C$. martii $(31.5$ and $50 \mu \mathrm{g} / \mathrm{ml})$ for $3 \mathrm{~h}$ at $37^{\circ} \mathrm{C}$, washed in PBS, and fixed with $2.5 \%$ glutaraldehyde in $0.1 \mathrm{M}$ sodium cacodylate buffer containing $1.0 \mathrm{mM} \mathrm{CaCl}_{2}$. Cells were then washed with $0.1 \mathrm{M}$ sodium cacodylate buffer and post-fixed for $1 \mathrm{~h}$ at room temperature in $1 \%$ osmium tetroxide plus $0.8 \%$ potassium ferrocyanide and $5 \mathrm{mM}$ calcium chloride. After rinsing, cells were dehydrated in acetone and embedded in Epon ${ }^{\circledR}$ resin. Ultrathin sections obtained in a Reichert Ultracut E ultramicrotome were stained with uranyl acetate and lead citrate, and observed in a Zeiss CEM-900 electron microscope. 


\section{RESULTS}

Antimicrobial susceptibility - The activity of the copaiba oils against Gram-positive bacteria using the microdilution technique is reported in Table. The in vitro antimicrobial activity was classified according to MIC values as follows: $\mathrm{MIC} \leq 100 \mu \mathrm{g} / \mathrm{ml}$, good; $100 \leq \mathrm{MIC} \leq$ $500 \mu \mathrm{g} / \mathrm{ml}$, moderate; $500 \leq \mathrm{MIC} \geq 1,000 \mu \mathrm{g} / \mathrm{ml}$, weak; $\mathrm{MIC} \geq 1,000 \mu \mathrm{g} / \mathrm{ml}$, inactive. Copaiba oils obtained from C. martii, $C$. officinalis and $C$. reticulata (collected in Acre) exhibited good antibacterial activity against Gram-positive bacteria, including MRSA, with a MIC range of $62.5-125 \mu \mathrm{g} / \mathrm{ml}$. In contrast, all oils tested were inactive against Gram-negative bacteria. Results of antifungal activity showed that oils from $C$. paupera and C. lucens exhibited moderate activity against T. rubrum and $M$. canis, and those from C. cearensis, C. langsdorffii and $C$. multijuga showed moderate activity only against T. rubrum $(\mathrm{MIC}=250-500 \mu \mathrm{g} / \mathrm{ml})$. Copaiba oils were inactive against $T$. mentagrophytes, $M$. gypseum or yeast. The solvent DMSO and the Petrolatum oil (NUJOL), used as an indifferent oil, showed no effect on the growth of microorganisms (data not shown). The MICs of the reference drugs used in this study (tetracycline, vancomycin, penicillin, oxacillin, nystatin, fluconazole, and

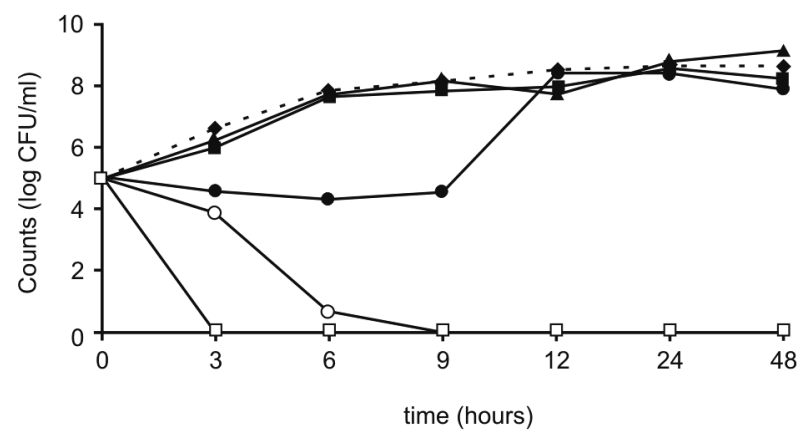

Fig. 1: time-kill curve of Staphylococcus aureus treated with copaiba oil obtained from Copaifera martii. $\star$ : control; $\mathbf{\Delta}$ : $0.12 \mathrm{MIC}$; $\mathbf{\square}: 0.25 \mathrm{MIC}$; •: 0.5 MIC; ०: 1.0 MIC; 口: 2.0 MIC. amphotericin B) were similar to those reported elsewhere. The times needed by the copaiba oil from $C$. martii to kill $S$. aureus are shown in Fig. 1. Analysis of the time-kill curves showed that after $3 \mathrm{~h}$ of treatment with copaiba oil at 2.0 X MIC, no viable cells remained. Furthermore, a steep decline in CFU/ml was observed after $6 \mathrm{~h}$ exposure when treated with 1.0 X MIC treatment. The concentration $0.5 \mathrm{X}$ MIC showed a bacteriostatic effect and a regrowth after $9 \mathrm{~h}$ of treatment. Concentrations equal to 0.25 and $0.12 \mathrm{X}$ MIC did not show activity. The time-kill curve of the same oil against MRSA was similar to Fig. 1.

Effect of copaiba oil from C. martii on the morphology and ultrastructure of $S$. aureus - Scanning and transmission electron microscopy analyses of untreated and treated $S$. aureus were performed in order to determine morphological and ultra-structural changes caused by at sub-inhibitory concentrations $(31.5$ and $50 \mu \mathrm{g} / \mathrm{ml})$ C. martii oil for $3 \mathrm{~h}$ (Figs 2, 3). In scanning electron microscopy, untreated $S$. aureus appeared to have a regular, smooth surface and was spherical in grape-like clusters (Fig. 2A). Bacteria treated with sub-inhibitory concentrations of the copaiba oil at 31.5 (Fig. 2B) and $50 \mu \mathrm{g} / \mathrm{ml}$ (Fig. 2C-D) for $3 \mathrm{~h}$ showed lysed and agglomerated cells. These morphological features in bacterial cells may be due to the action on the cell wall followed by loss of cell volume. These data were confirmed by transmission electron microscopy (Fig. 2F). Control cells demonstrated their structural integrity with a thicker cell wall (Figs 2E, 3A-B). In addition, transmission electron microscopy analyses of $S$. aureus treated with oil from $C$. martii showed the cell wall being disrupted and damaged, resulting in a release of cytoplasmatic compounds (Fig. 3C), loss of cell walls (Fig. 3D), alterations in morphology, and decrease in cell volume (Fig. 3E-H).

\section{DISCUSSION}

There are more than 20 species of Copaifera genus in Brazil, which provide oils that differ significantly in chemical composition. The main constituents of these oils are sesquiterpenes and diterpenes (Braga et al. 1998,

TABLE

Antimicrobial activity (minimal inhibitory concentration/minimal bactericidal concentration in $\mu \mathrm{g} / \mathrm{ml}$ ) of copaiba oil obtained from several species of Copaifera genus

\begin{tabular}{lccccc}
\hline Oils/Ref antibiotic & $\begin{array}{c}\text { Staphylococcus } \\
\text { aureus }\end{array}$ & $\begin{array}{c}\text { Methicillin-resistant } \\
\text { Staphylococcus aureus }\end{array}$ & $\begin{array}{c}\text { Bacillus } \\
\text { subtilis }\end{array}$ & $\begin{array}{c}\text { Staphylococcus } \\
\text { epidermidis }\end{array}$ & $\begin{array}{c}\text { Enterococcus } \\
\text { faecalis }\end{array}$ \\
\hline Copaifera reticulata (Pará) & $>1,000 / \mathrm{nt}$ & $1,000 / 1,000$ & $250 / 250$ & $1,000 />1,000$ & $250 / 1,000$ \\
Copaifera reticulata (Acre) & $62.5 / 62.5$ & $125 / 250$ & $31.25 / 31.25$ & $62.5 / 62.5$ & $62.5 / 62.5$ \\
Copaifera martii & $62.5 / 62.5$ & $62.5 / 125$ & $15.62 / 31.25$ & $62.5 / 62.5$ & $62.5 / 62.5$ \\
Copaifera cearensis & $250 / 1,000$ & $125 / 500$ & $62.5 / 125$ & $250 / 500$ & $500 / 1,000$ \\
Copaifera paupera & $250 / 1,000$ & $250 / 500$ & $62.5 / 62.5$ & $1,000 / 1,000$ & $62.5 / 500$ \\
Copaifera langsdorfii & $>1,000 / \mathrm{nt}$ & $>1,000 / \mathrm{nt}$ & $62.5 / 62.5$ & $>1,000 / \mathrm{nt}$ & $>1,000 / \mathrm{nd}$ \\
Copaifera officinalis & $62.5 / 62.5$ & $125 / 250$ & $31.25 / 31.25$ & $31.25 / 31.25$ & $31.25 / 62.5$ \\
Copaifera multijuga & $500 / 1,000$ & $125 / 250$ & $125 / 125$ & $1000 />1000$ & $250 / 500$ \\
Copaifera lucens & $125 / 500$ & $>1,000 / \mathrm{nt}$ & $125 / 250$ & $250 / 1000$ & $1,000 / 1,000$ \\
Penicillin & $0.075 / \mathrm{nt}$ & $\mathrm{nt}$ & $\mathrm{nt}$ & $10.0 / \mathrm{nt}$ & 0.15 \\
Vancomycin & $\mathrm{nt}$ & $\mathrm{nt}$ & $0.78 / \mathrm{nt}$ & $\mathrm{nt}$ & $\mathrm{nt}$ \\
Oxacyline & $\mathrm{nt}$ & $>500 / \mathrm{nt}$ & $\mathrm{nt}$ & $\mathrm{nt}$ & $\mathrm{nt}$ \\
\hline
\end{tabular}

nt: not tested. 


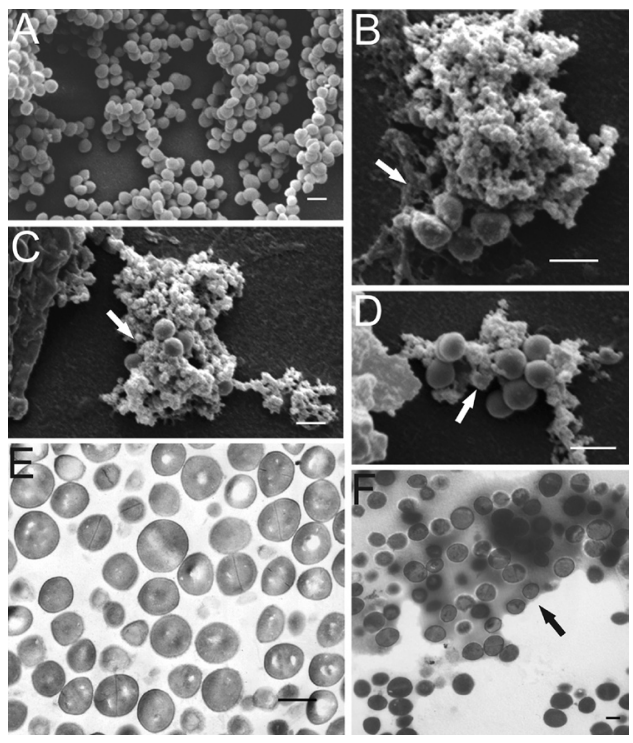

Fig. 2: scanning electron microscopy and transmission electron microscopy of Staphylococcus aureus treated with copaiba oil obtained from Copaifera martii for $3 \mathrm{~h}$ at $37^{\circ} \mathrm{C}$. A and E: control; B and F: $31.5 \mu \mathrm{g} / \mathrm{ml}$; $\mathrm{C}$ and D: $50 \mu \mathrm{g} / \mathrm{ml}$. Bars $=1 \mu \mathrm{m}$.

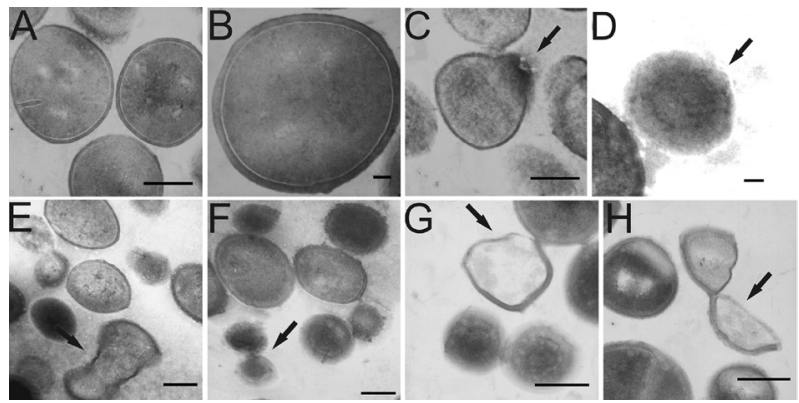

Fig. 3: transmission electron microscopy of Staphylococcus aureus treated with copaiba oil obtained from Copaifera martii for $3 \mathrm{~h}$ at $37^{\circ} \mathrm{C}$. A and B: control; C, E, F, G, H: $31.5 \mu \mathrm{g} / \mathrm{ml}$; D: $50 \mu \mathrm{g} / \mathrm{ml}$. Bars $\mathrm{A}, \mathrm{C}, \mathrm{E}, \mathrm{F}=1 \mu \mathrm{m} ; \mathrm{B}$ and $\mathrm{D}=0.1 \mu \mathrm{m}$.

Veiga-Júnior et al. 2001). Although different activities have been reported and a variety of substances have been identified, little is known about the relationship between the structures and activity of the components (Tincusi et al. 2002). Sesquiterpenes comprise about $80 \%$ of the oils; the most common are $\alpha$-copaene, $\beta$-cariofilene, $\beta$-bisabolene, $\alpha$ and $\beta$-selinene, $\alpha$-humulene, and $\delta$ and $\gamma$-cadidene (Veiga-Júnior \& Pinto 2002). The present study was designed to evaluate the antimicrobial activities of copaiba oils obtained from several species of Copaifera. Copaiba oils obtained from C. martii, C. officinalis and C. reticulata (collected in Acre) showed in vitro bactericidal activity against a wide spectrum of Gram-positive organisms. This spectrum includes MRSA, for which there are very few therapeutic alternatives (Samuelsen et al. 2005). Despite many recent advances in antimicrobial therapy, resistance among Gram-positive pathogens continues to pose a serious and growing clinical problem. Increasing resistance has created a need for new antimicrobial agents. The major compounds of C. martii, C. officinalis, and C. reticulata (Acre) are 3-alpha-hydroxy-copalic acid, hardwickiic acid, and $\alpha$-copaene, respectively (Veiga-Junior \& Pinto 2002, Oliveira et al. 2006).

Variation in chemical composition is common among different species and even among individual trees (Cascon \& Gilbert 2000). For example, resin oils from C. reticulata collected in Acre and Pará showed differences in activity against bacteria because of differences in chemical composition.

Both prokaryotes (bacteria) and eukaryotes (yeast and dermatophytes) were included in the present study. Copaiba oils showed good activity only against Grampositive bacteria, and moderate activity against dermatophytes. B. subtilis was the most sensitive organism. Interestingly enough, copaiba oils were active not only against a wild strain of $S$. aureus, but also against MRSA. Morphological and ultrastructural alterations of the bacterium treated with copaiba oils for $3 \mathrm{~h}$ were revealed by scanning and transmission electron microscopy. Cell wall disruption, release of cytoplasmatic compounds, and decreased cellular volume were observed, indicating that the copaiba oil from C. martii might affect the cell wall. Additionally, for the time-kill curve, copaiba oils showed good and rapid bactericidal activity within $3 \mathrm{~h}$. The observations from electron microscopy seemed to be well correlated with the effects observed in the time-kill experiment.

In conclusion, the results of the present study suggest that copaiba oils may be potential sources of new and selective agents for the treatment of important infectious diseases. Further laboratory and clinical studies of these oils are required in order to understand their antibacterial principles.

\section{ACKNOWLEDGEMENTS}

To Dr José Andrés Morgado-Díaz, INCa - Rio de Janeiro, for performing the transmission electron microscopy.

\section{REFERENCES}

Araújo-Junior FA, Braz MN, Rocha-Neto OG, D'Almeida Costa F, Brito MVH 2005. Copaiba oil effect in rats aminotransferases submitted to hepatic ischemic and reperfusion with and without preconditioning. Acta Cir Bras 20: 93-99.

Braga WF, Rezende CM, Antunes OAC, Pinto AC 1998. Terpenoids from Copaifera cearensis. Phytochemistry 49: 263-264.

Brito MVH, Moreira RJ, Tavares MLC, Carballo MCS, Carneiro TX, Santos AAS 2005. Copaiba oil effect on urea and creatinine serum levels in rats submitted to kidney ischemia and reperfusion syndrome. Acta Cir Bras 20: 243-246.

Carvalho JCT, Cascon V, Possebon LS, Morimoto MSS, Cardoso LGV, Kaplan MAC, Gilbert B 2005. Topical antiinflamatory and analgesic activities of Copaifera duckei Dwyer. Phytother Res 19: 946-950.

Cascon V, Gilbert B 2000. Characterization of the chemical composition of oleoresins of Copaifera guianensis Desf., Copaifera duckei Dwyer and Copaifera multijuga Hayne. Phytochemistry 55: 773-778.

CLSI - Clinical and Laboratory Standards Institute 2005a. Approved standard M7-A6. Methods for dilution antimicrobial susceptibility tests for bacteria that grow aerobically, Pennsylvania, $49 \mathrm{p}$. 
CLSI - Clinical and Laboratory Standards Institute 2005b. Approved standard M27-A2. Reference method for broth diluition antifungical susceptibility testing of yeasts, Pennsylvania, $43 \mathrm{p}$.

CLSI - Clinical and Laboratory Standards Institute 2005c. Approved standard M38-A. Reference method for broth microdilution test for screening of filamentous fungi, Pennsylvania, $48 \mathrm{p}$.

Costa-Lotufo LV, Cunha GMA, Farias PAM, Viana GSB, Cunha KMA, Pessoa C, Moraes MO, Silveira ER, Gramosa NV, Rao VSN 2002. The cytotoxic and embryotoxic effects of kaurenoic acid, a diterpene isolated from Copaifera langsdorffii oleo-resin. Toxicon 40: 1231-1234.

Fung HB, Kirschenbaum HL, Ojofeitimi BO 2001. Linezolid: an oxazolidinone antimicrobial agent. Clin Ther 23: 356-391.

Gilbert B, Teixeira DF, Carvalho ES, De Paula AE, Pereira JF, Ferreira JL, Almeida MB, Machado RS, Cascon V 1999. Activities of the pharmaceutical technology Institute of the Oswaldo Cruz Foundation with medicinal, insecticidal and insect repellent plants. An Acad Bras Cienc 71: 265-271.

Gomes NM, Rezende CM, Fontes SP, Matheus ME, Fernandes PD 2007. Antinociceptive activity of Amazonian copaiba oils. J Ethnopharmacol 12: 486-492.

Lima SRM, Veiga-Jr VF, Christo HB, Pinto AC, Fernandes PD 2003. In vivo and in vitro studies on the anticancer activity of Copaifera multijuga Hayne and its fractions. Phytother Res 17: 1048-1053.

Okdakowska-Jedynak U, Paczek L, Krawczyk M, Zieniewicz K, Nyckowski P, Pawiak J, Patkowiski W, Skwarek A, Paczkowska A 2003. Resistence of Gram-positive pathogens to antibiotic is a therapeutic challenge after liver transplantation: clinical experience in one center with linezolid. Transplant Proc 35: 2304-2306.

Oliveira ECP, Lameira OA, Zoghbi MGB 2006. Identificação da época de coleta do óleo-resina de copaiba (Copaifera spp.) no município de Moju, PA. Rev Bras Pl Med 3: 14-23.
Paiva LAF, Gurgel LA, Campos AR, Silveira ER, Rao VSN 2004a. Attenuation of ischemia/reperfusion-induced intestinal injury by oleoresin from Copaifera langsdorffii in rats. Life Sci 75: 1979-1987.

Paiva LAF, Gurgel LA, De Souza ET, Silveira ER, Silva RM, Santos FA, Rao VSN 2004b. Protective effect of Copaifera langsdorffii oleo-resin against acetic acid-induced colitis in rats. J Ethnopharmacol 93: 51-56.

Samuelsen O, Haukland HH, Kahl BC, von Eiff C, Proctor RA, U1vatne H, Sandvik K, Vorland LH 2005. Staphylococcus aureus small colony variants are resistant to the antimicrobial peptide lactoferrin B. J Antimicrob Chemother 56: 1126-1129.

Shu Y 1998. Recent natural products based drug development: a pharmaceutical industry perspective. J Nat Prod 61: 1053-1071.

Tincusi BM, Jiménez IA, Bazzocchi IL, Moujir LM, Mamani ZA, Barroso JP, Ravelo AG, Hernández BV 2002. Antimicrobial terpenoids from the oleoresin of the peruvian medicinal plant $\mathrm{Co}$ paifera paupera. Planta Med 68: 808-812.

Veiga-Junior VF, Pinto AC 2002. The Copaifera L. genus. Quim Nova 25: 273-286.

Veiga-Júnior VF, Rosas EC, Carvalho MV, Henriques MGMO, Pinto AC 2007. Chemical composition and anti-inflammatory activity of copaiba oils from Copaifera cearensis Huber ex Ducke, Copaifera reticulata Ducke and Copaifera multijuga Hayne-A comparative study. J Ethnopharmacol 112: 248-254.

Veiga-Junior VF, Zunino L, Calixto JB, Patitucci ML, Pinto AC 2001. Phytochemical and antioedematogenic studies of commercial copaiba oils available in Brazil. Phytother Res 15: 476-480.

Veiga-Júnior VF, Zunino L, Patitucci ML, Pinto AC, Calixto JB 2006. The inhibition of paw oedema formation caused by the oil of $\mathrm{Co}$ paifera multijuga Hayne and its fractions. J Pharm Pharmacol 58: 1405-1410.

Zetola N, Francis JS, Nuermberger EL, Bishai WR 2005. Community-acquired methicillin-resistant Staphylococcus aureus: an emerging threat. Lancet Infect Dis 5: 275-286. 